\title{
Typology of historical cultural landscapes based on their cultural elements
}

\author{
JAKUB JELEN ${ }^{1}$, MARKÉTA ŠANTRU゚ČKOVÁ ${ }^{2}$, MAREK KOMÁREK ${ }^{1}$
}

1 Charles University, Faculty of Science, Department of Social Geography and Regional Development, Prague, Czechia; e-mail: jakub.jelen@natur.cuni.cz, marek.komarek@natur. cuni.cz

2 The Silva Tarouca Research Institute for Landscape and Ornamental Gardening, Průhonice, Czechia; e-mail: Marketa.Santruckova@vukoz.cz

ABSTRACT Historical cultural landscapes represent numerous values and meanings that are important for today's society. These cultural landscapes document the specific development of local communities and may reflect their approaches or attitudes toward the environment. Man-made landscape elements are created for special purposes and represent specific values (historical, cultural, environmental, economic, etc.). The analysis of these landscape elements allows us to find out for what purposes the society decided to use the landscape, respectively what functions the landscape performs and what historical or cultural values it represents. The following text presents a typology of historical cultural landscapes based on a cluster analysis of cultural landscape features. Using this method, a typology of landscapes is created that reflects the functional use and values of landscapes based on the analysis of cultural-historical elements and differentiates the rates and methods of land use by human beings. The output of the cluster analysis is visualized in a dendrogram, based on which seven basic landscape categories were defined and described.

KEY WORDS historical cultural landscapes - cultural elements - typology - cluster analysis dendrogram

JELEN, J., ŠANTRU゚ČKovÁ, M., KOMÁREK, M. (2021): Typology of historical cultural landscapes based on their cultural elements. Geografie, 126, 3, 243-261.

https://doi.org/10.37040/geografie2021126030243

Received February 2021, accepted July 2021.

(C) Česká geografická společnost, z. s., 2021 


\section{Introduction}

Landscapes are part of life in human society, and all processes and changes in natural and cultural relationships occur in landscapes. Thus, the landscape is an object of interest to many experts from many scientific disciplines, e.g., geography, cartography, monument care, regional planning and development (Lowenthal 2007, Mitchell 2008). There are many discussions regarding how to define landscape and the actual definitions of landscape represent the result of an evolution lasting about 200 years. When we are defining the term, what primarily matters is who is trying to define it and for what purpose. The most significant discipline that addresses landscapes is geography, in which we can observe differences among subspecialties, such as a history, archaeology, landscape ecology and land-use or cultural geography, as well as the development of this discipline over time and of geographic thinking in general (Daugstad, Grytli 1999; Antrop 2013; Turner 2018).

Depending on how a particular landscape is defined and subsequently named, it receives different descriptions or attributes that better characterize it. On the transnational level, the term "landscape" is defined in documents, such as Natura 2000, Agenda 21, the UNESCO Convention and the European Landscape Convention. There are a large number of studies that address the definition of landscape and many that focus on creating a typology of the geographic characteristics of a landscape in terms of, e.g., altitude, climate, geology, soils and land use/land cover (Lipský, Romportl 2007).

The first step in landscape categorization can be considered defining the difference between natural and cultural landscapes, whereby the cultural landscape results from the transformation of the natural landscape (Sauer 1925). Natural landscapes only occur without the influence of man and existed long before man appeared. Typologies of natural landscapes are primarily based on quantifiable physical-geographic or biological aspects and on physical-geographical delineation (Romportl, Chuman, Lipský 2013; Kolejka 2014).

In contrast, cultural landscapes are primarily based on the combination of natural and human activities that occur in the area of interest (Taylor, Lennon 2011). Cultural landscape is the most recent meaning and the individual European geographical schools (e.g. French, German or Anglo-Saxon) have built strong theoretical decks. These various concepts are discussed in many professional publications (Sauer 1925; Lowenthal 2007; Taylor, Lennon 2011). Human influence is often discussed, and quantitative data are used that can be obtained through remote-sensing methods. We know that the definition of a landscape always depends on the subjective view of the assessor; it is always important to perceive all the elements of the landscape at the same time and at a sufficient distance (Kučera 2009). The history of the landscape is also important, i.e., the events that occurred in the area and how they are reflected in the current state and perception of the 
landscape. A cultural landscape reflects the story of the people who shaped it, not only in the past but also in the present. To identify the type of cultural landscape, both the natural and cultural elements in place must be considered as a whole (Sirisrisak, Akagawa 2007; Howard, Thompson, Waterton, eds. 2013). Research on cultural landscapes in their entirety represents a means to better understand human settlements and economic activities, the spatial behaviour of such settlements and activities, and the related and changing landscape (Lowenthal 1990, Bičík 2004, Kupka 2010).

Despite, or rather, because we perceive a cultural landscape, studying and observing it each and every day, there are a number of approaches and source examples (Lowenthal 2007, Mitchell 2008). The definition of particular cultural landscape types in principle uses three approaches: holistic, expert or quantitative (Romportl, Chuman 2012). The holistic approach reflects a holistic perception of the landscape and emphasizes its indivisibility (Van Eetvelde, Antrop 2009). The expert approach highlights the invaluable experience of landscape experts and users (Antrop 1997), and the quantitative typology emphasizes the repeatability of the definition of the landscape units and the minimization of the subjective factor (Schulte, Mladenoff, Nordheim 2002; Lipský, Romportl 2007; Chuman, Romportl 2010; Morgan, Gergel 2010). On the basis of a broad definition of cultural landscape, a large number of studies have been carried out to examine specific types of landscapes and their specific values (Taylor, Lennon 2011).

The identification of landscape values is the first step in determining the limits of land use, landscape activities and protection. Each landscape has certain values, and each landscape is a repository of cultural values (Šantrůčková, Weber 2016). Since the definition of values is very subjective, the given values need not be manifested; they can only be significant for a particular population. Clearly, values may not be significant on a global scale but may be only local or personal. Therefore, it cannot be said that a certain type of landscape does not contain or represent any values. Value has a certain weight, and the value of a given tangible or intangible element has hidden features of those elements. Values can take on various dimensions: historical, cultural, social, environmental, educational, social, economic, natural, etc.

The paper is focused on the historical cultural landscape, i.e. the specific part of cultural landscape with significant landscape values and preserved landscape elements as tangible heritage (Kolejka, Krejčí, Nováková 2020; Ehrlich et al. 2020). Our approach is based on the presence of the landscape elements and their continuity (Bergès, Dupouney 2021; Šantrůčková et al. 2020). It takes account of (landscape) legacy effect which include pattern and processes (Tappeiner et al. 2020). As well as the (forest) transition concept (Mather et al. 1998; Rudel, Schneider, Uriarte 2010) legacy effect include time factor and changes of the landscape elements during historical periods. 
In defining the typology of a historical cultural landscape, it is therefore important to realize which values of the landscape are hidden and which might be beneficial. There are many works aimed at defining the values of protected landscape areas, monuments, areas and properties included in the UNESCO list and other important sites and localities (Smith 2006, Stephenson 2008). One goal is defining the values of elements that are generally related to heritage, i.e., elements that represent specific values and meanings in which attempts and tendencies have been made to preserve and pass them on to the next generation (Smith 2006; Capelo, Barata, Mascarenhas 2011). These values are significant; they mean something extraordinary, and efforts are made to preserve them (for any reason). These are, therefore, values that can be described as being above average in some respects, that is, values that are not present in a common landscape or area and are something extraordinary. In each territory, however, it is possible to identify certain values that are not necessarily of national or international significance and may appear to be "average" but still have their place and shape the landscape.

To create a classification of historical cultural landscapes, it is first necessary to identify the most important elements found in the landscape. There are many cultural elements in the landscape that are involved in shaping its character. In this study, the expert approach was used to define the concurrent values of individual landscape features in tandem with a quantitative approach that assembled the individual landscape features into combinations, eliminating the subjective factor (Chuman, Romportl 2010; Fairclough 2016).

Even before creating the typology itself, it is possible to determine the input hypotheses: a) the typology created by cluster analysis will reflect and combine historical cultural landscapes that were individually identified by several authors in their model areas (Scazzosi 2004; Vorel 2005; Kupka 2010; Gfeller 2013; Gullinoa, Larcher 2013; Latocha 2015; b) the types of historical cultural landscape will clustered according the main human activity and values (Sirisrisak, Akagawa 2007; Rössler 2006). The main aim of this paper is to create a typology of historical cultural landscape based on specific landscape elements, including their functions and values, within which it would be possible to categorize a landscape into subspecific units (Prats, Salin 2016).

\section{Data and methods}

\subsection{Analysis of historical cultural landscape elements}

The first step was to review the relevant literature and create a set of historical cultural landscape elements. Partial elements were selected from studies that address specific landscapes (Scazzosi 2004; Vorel 2005; Kupka 2010; Gfeller 2013; 
Gullinoa, Larcher 2013; Latocha 2015; Lieskovský et al. 2015). The set of selected historical cultural landscape elements (totaly 51, see Table 1) represents Central European landscape.

We take the cultural landscape elements which are traces from the history and are preserved to nowadays. For example not all buildings and other artificial constructions such as factories, quarries, railways were used for analysis but only that ones that are appreciated by society for its age (historical value) and arts and crafts (artistic value; Riegl 2003, Horáček 2015). Similarly not all forests, meadows, fields, and other landscape structures but that ones with preserved small scale structure, area continuity, and old methods of management (for details see e.g. Kolejka, Krejčí, Nováková 2020; Bergès, Dupouney 2021; Skokanová, Eremiášová 2012; Lieskovský et al. 2015). Because we use the concept of continuity, we should set a time horizon for the historical value of the landscape elements. Based on the accessible data and long-term changes of the European landscape, the year 1960 was set down. Landscape changes accelerated in both, Western and Eastern Europe since the late 1950s (Skokanová, Eremiášová 2012; Bender et al. 2005; Lieskovský et al. 2015).

The selected historical cultural landscape elements differ from each other also by their area and shape (points, lines, polygons). The shape and area of landscape elements are important in landscape analysis of the model regions (Lieskovský et al. 2015; Šantrǔčková et al. 2020). However, we decided to analyse the landscape elements according their functional values. The shape and area do not determine the historical cultural value, so they do not affect the analysis and could be neglect.

The selection of the historical cultural landscape elements was followed by their internal analysis, i.e. the creation of a short definition and the determination of the primary function (meaning) and, if necessary, the secondary function (e.g. if the primary function had been lost). The function is closely connected to values in our approach. Certain elements may represent multiple functions and values, depending on their actual use or status. An expert approach was applied to set twelve basic aggregated functions interconnected with values. Of course, other functions could be distinguished and used for more detailed analysis, e.g. recreational function is aggregated with residential, etc. As well as an expert approach was applied to assign individual values to given elements, i.e. a detailed analysis of a given element based on its characteristics.

A matrix containing information on whether or not a given element represents different functions and individual values for all individual historical cultural landscape elements was established. A source matrix is given in Table 1. For each element, it was evaluated whether it represents (yes $=1$ ) or does not represent $($ no $=0)$ the given values (agricultural, environmental, forestry, industrial, memorial, military, mining, religious, representative, residence, transport or hydrology). 
Table 1 - The data matrix that serves as a source for cluster analysis

\begin{tabular}{|c|c|c|c|c|c|c|c|c|c|c|c|c|c|}
\hline \multirow{2}{*}{\multicolumn{2}{|c|}{ No. Element }} & \multicolumn{12}{|c|}{ Functions-values } \\
\hline & & 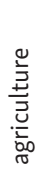 & 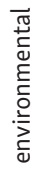 & 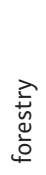 & 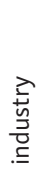 & 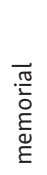 & 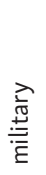 & 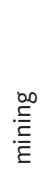 & $\begin{array}{l}\cong \\
\frac{0}{0} \\
\frac{.0}{ \pm 0}\end{array}$ & 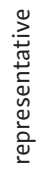 & 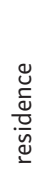 & 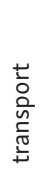 & 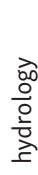 \\
\hline 1 & battlefield & 0 & 0 & 0 & 0 & 1 & 1 & 0 & 1 & 0 & 0 & 0 & 0 \\
\hline 2 & bunker & 0 & 0 & 0 & 0 & 1 & 1 & 0 & 0 & 0 & 0 & 0 & 0 \\
\hline 3 & calvary / cross way & 0 & 0 & 0 & 0 & 1 & 0 & 0 & 1 & 1 & 0 & 0 & 0 \\
\hline 4 & canals & 1 & 1 & 1 & 1 & 0 & 0 & 1 & 0 & 0 & 0 & 1 & 1 \\
\hline 5 & castle & 0 & 0 & 0 & 0 & 1 & 1 & 0 & 0 & 1 & 1 & 0 & 0 \\
\hline 6 & cemetery / burial site & 0 & 0 & 0 & 0 & 1 & 1 & 0 & 1 & 1 & 0 & 0 & 0 \\
\hline 7 & cross & 1 & 0 & 1 & 0 & 1 & 1 & 0 & 1 & 1 & 0 & 1 & 0 \\
\hline 8 & coppice & 1 & 1 & 1 & 0 & 0 & 0 & 0 & 0 & 0 & 0 & 0 & 0 \\
\hline 9 & country lane / hedge & 1 & 1 & 1 & 1 & 0 & 0 & 0 & 0 & 0 & 0 & 0 & 0 \\
\hline 10 & drill & 0 & 0 & 0 & 1 & 0 & 0 & 1 & 0 & 0 & 0 & 0 & 1 \\
\hline 11 & dump & 0 & 1 & 0 & 1 & 0 & 0 & 1 & 0 & 0 & 0 & 0 & 0 \\
\hline 12 & farm & 1 & 0 & 0 & 0 & 0 & 0 & 0 & 0 & 0 & 1 & 0 & 0 \\
\hline 13 & field & 1 & 0 & 0 & 0 & 0 & 0 & 0 & 0 & 0 & 0 & 0 & 0 \\
\hline 14 & flower meadow & 1 & 1 & 0 & 0 & 0 & 0 & 0 & 0 & 0 & 0 & 0 & 0 \\
\hline 15 & forest & 0 & 1 & 1 & 0 & 0 & 0 & 0 & 0 & 0 & 0 & 0 & 0 \\
\hline 16 & fortress & 0 & 0 & 0 & 0 & 1 & 1 & 0 & 0 & 0 & 1 & 0 & 0 \\
\hline 17 & gallery & 0 & 0 & 0 & 1 & 0 & 1 & 1 & 0 & 0 & 0 & 0 & 0 \\
\hline 18 & granary & 1 & 0 & 0 & 0 & 0 & 0 & 0 & 0 & 1 & 0 & 0 & 0 \\
\hline 19 & game park & 0 & 1 & 1 & 0 & 0 & 0 & 0 & 0 & 1 & 0 & 0 & 0 \\
\hline 20 & hop garden & 1 & 0 & 0 & 0 & 0 & 0 & 0 & 0 & 0 & 0 & 0 & 0 \\
\hline 21 & chapel & 0 & 0 & 0 & 0 & 1 & 1 & 0 & 1 & 1 & 0 & 0 & 0 \\
\hline 22 & chateau / manor house & 0 & 0 & 0 & 0 & 1 & 0 & 0 & 0 & 1 & 1 & 0 & 0 \\
\hline 23 & chimney & 0 & 0 & 0 & 1 & 0 & 0 & 1 & 0 & 0 & 0 & 0 & 0 \\
\hline 24 & church / cathedral & 0 & 0 & 0 & 0 & 1 & 0 & 0 & 1 & 1 & 0 & 0 & 0 \\
\hline 25 & industrial building / factory & 0 & 0 & 0 & 1 & 0 & 0 & 1 & 0 & 1 & 0 & 1 & 1 \\
\hline 26 & landfill & 0 & 0 & 0 & 1 & 0 & 0 & 1 & 0 & 0 & 0 & 0 & 0 \\
\hline 27 & memorial / monument & 0 & 0 & 0 & 0 & 1 & 1 & 0 & 1 & 1 & 0 & 0 & 0 \\
\hline 28 & mill & 1 & 0 & 0 & 1 & 0 & 0 & 1 & 0 & 0 & 1 & 0 & 1 \\
\hline 29 & military area & 0 & 0 & 0 & 0 & 1 & 1 & 0 & 0 & 0 & 0 & 0 & 0 \\
\hline 30 & mine & 0 & 0 & 0 & 1 & 0 & 0 & 1 & 0 & 0 & 0 & 0 & 0 \\
\hline 31 & mining tower & 0 & 0 & 0 & 1 & 0 & 0 & 1 & 0 & 0 & 0 & 0 & 0 \\
\hline 32 & orchard & 1 & 1 & 0 & 0 & 0 & 0 & 0 & 0 & 0 & 0 & 0 & 0 \\
\hline 33 & ornamental garden & 0 & 1 & 0 & 0 & 1 & 0 & 0 & 0 & 1 & 1 & 0 & 0 \\
\hline 34 & extensive pasture & 1 & 1 & 0 & 0 & 0 & 0 & 0 & 0 & 0 & 0 & 0 & 0 \\
\hline 35 & woody pasture & 1 & 1 & 1 & 0 & 0 & 0 & 0 & 0 & 0 & 0 & 0 & 0 \\
\hline 36 & paths & 1 & 0 & 1 & 0 & 1 & 1 & 0 & 1 & 0 & 1 & 1 & 0 \\
\hline 37 & pheasantry & 0 & 1 & 1 & 0 & 0 & 0 & 0 & 0 & 1 & 0 & 0 & 0 \\
\hline 38 & pond & 1 & 1 & 1 & 1 & 0 & 0 & 1 & 0 & 0 & 0 & 0 & 1 \\
\hline 39 & quarry & 0 & 1 & 0 & 1 & 0 & 0 & 1 & 0 & 0 & 0 & 0 & 0 \\
\hline 40 & railway & 0 & 0 & 1 & 1 & 0 & 1 & 1 & 0 & 0 & 0 & 1 & 0 \\
\hline
\end{tabular}




\begin{tabular}{|c|c|c|c|c|c|c|c|c|c|c|c|c|c|}
\hline \multirow{2}{*}{\multicolumn{2}{|c|}{ No. Element }} & \multicolumn{12}{|c|}{ Functions-values } \\
\hline & & 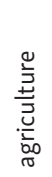 & 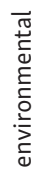 & 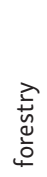 & 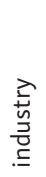 & 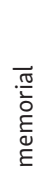 & 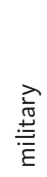 & 号 & 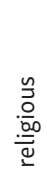 & 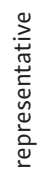 & 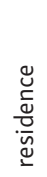 & 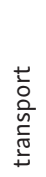 & $\begin{array}{l}\text { ते } \\
\text { 을 } \\
\text { 음 } \\
\text { ㄷ }\end{array}$ \\
\hline 41 & reservoir / water dam & 1 & 0 & 1 & 1 & 0 & 0 & 1 & 0 & 0 & 0 & 0 & 1 \\
\hline 42 & road & 1 & 0 & 1 & 1 & 1 & 1 & 1 & 1 & 1 & 1 & 1 & 0 \\
\hline 43 & statue & 1 & 0 & 1 & 1 & 1 & 1 & 1 & 1 & 1 & 1 & 1 & 0 \\
\hline 44 & wall & 1 & 0 & 1 & 1 & 0 & 1 & 1 & 1 & 1 & 0 & 0 & 0 \\
\hline 45 & transmitter & 0 & 0 & 0 & 1 & 0 & 1 & 1 & 0 & 0 & 0 & 1 & 0 \\
\hline 46 & tree line / alley & 1 & 1 & 1 & 0 & 1 & 0 & 0 & 1 & 1 & 0 & 1 & 0 \\
\hline 47 & trench & 1 & 0 & 1 & 1 & 0 & 1 & 1 & 0 & 0 & 0 & 1 & 0 \\
\hline 48 & vineyard & 1 & 0 & 0 & 0 & 0 & 0 & 0 & 0 & 0 & 0 & 0 & 0 \\
\hline 49 & warehouse & 1 & 0 & 0 & 1 & 0 & 0 & 1 & 0 & 0 & 0 & 0 & 0 \\
\hline 50 & watercourse & 1 & 1 & 1 & 1 & 0 & 0 & 1 & 0 & 0 & 0 & 1 & 1 \\
\hline 51 & well & 1 & 0 & 0 & 1 & 0 & 0 & 1 & 0 & 0 & 0 & 0 & 1 \\
\hline
\end{tabular}

Source: authors

\subsection{Cluster analysis}

After the element matrix was created, cluster analysis was conducted to determine individual clusters that represent specific historical cultural landscape types. Cluster analysis is a multidimensional method designed directly for objective and systematic classification of individual elements to groups (clusters) by assessing their similarities and differences. The aim of the cluster analysis is to set groups of elements when the similarities of the elements in one group is higher then differences of the elements in different groups (Tryon 1939). Cluster analysis and hierarchical organization was used by Merhautová 2009 for clasification of the cultural landscape in Bohemian Paradise (Czechia). Pătru-Stupariu, Pascu, Bürgi (2019) used cluster analysis for assessing resilience of the tangible and intangible heritage in Transylvania (Romania).

The input data were analysed using hierarchical cluster analysis. During searching for the optimal level of similarity of selected groups, several options measures were considered with using method of between-group linkage (occasionally referred to as category average). Because the source matrix has binary character (the value " 1 " means the presence of the attribute, the value " 0 " the absence) there was no need to standardize the data and the binary measure Squared Euclidean distance was chosen. Thus, objects were clustered when the smallest average Euclidean distance between two objects not belonging to the same cluster was identified. The distance between clusters is thus the average distance of all points in the clusters. 
canals

watercourse

pond

reservoir / water dain

well

mill

road

transmitter

mining tower

quarry

mine

landfill

chimney

dump

warehouse

gallery

drill

wall

industrial building / factory

railway

trench

game park

pheasantry

forest

extensive pasture

$>$ vineyard

orchard

hop garden

flower meadow

field

granary

farm

coppice

Woody pasture

paths

country lane / hedge

calvary / cross way

church / cathedral

tree line $/$ alley

chapel

memorial / monument

cross

Cemetery / burial site

statue

battlefield

chateau / manor house

ornamental garden

castle

bunker

military area

fortress
Dendrogram using Average Linkage (Between Groups)

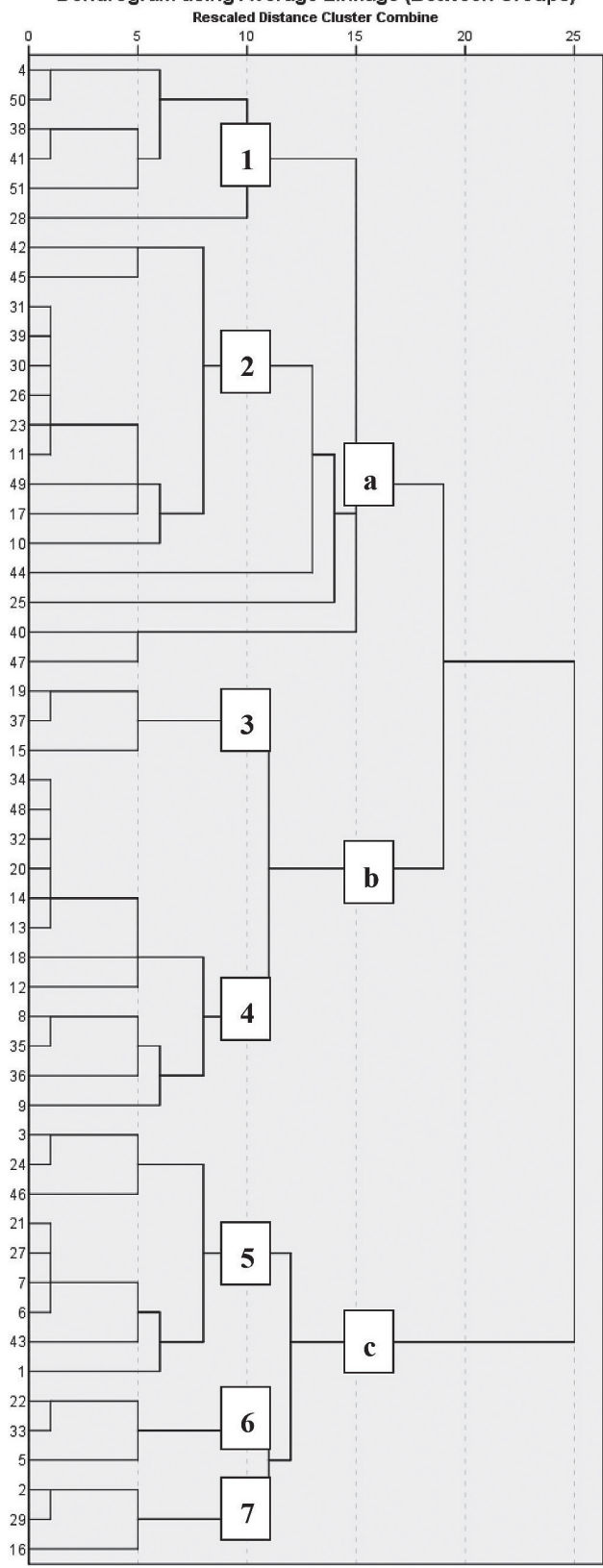

$$
1=\text { water }
$$

$2=$ industry

$3=$ forestry

$4=$ agriculture

$5=$ memorial $/$ religious

$6=$ designed

$7=$ military $\mathrm{a}=$ productive landscapes

$\mathrm{b}=$ harvesting landscapes

$\mathrm{c}=$ heritage landscapes

Fig. 1 - The historical cultural landscape types according the cluster analysis dendrogram 
The output of the analysis was visualized in a dendrogram (Hartigan 1975; Taylor, Schejter 2013; Giné 2018). The dendrogram is the result of the method and measure used for the values in the source matrix. The incision through dendrogram (Fig. 1) was proved by expert opinion of the authors in step 10 ( 7 clusters) and in step 15 (3 clusters) where the historical cultural landscape elements were logically grouped (see e.g. Rössler 2006).

\section{Results}

The cluster analysis was performed by selecting the 51 historical cultural landscape elements that are most commonly mentioned in the studied papers. The final cluster analysis dendrogram is shown in Figure 1, and clusters were created by incision in step 10. Based on the element analysis, seven basic landscape categories were defined:

1. Water management landscape

2. Industrial landscape

3. Forestry landscape

4. Agricultural landscape

5. Memorial/religious landscape

6. Designed landscape

7. Military landscape

The analysis reveals that certain historical cultural landscape elements create clusters in the first steps of a dendrogram (e.g., elements characteristic of mining - mining tower, quarry, mine, etc.), which is due to their apparent specific and similar characteristics and values. The same can be observed in a cluster of elements related to agricultural production (vineyard, orchard, hop garden, etc.). However, it is possible to find four elements that in the first stage (in step 10) do not fit any type of landscape: e.g. a wall, an industrial building/factory, a railway, and a trench. These historical cultural landscape elements could logically be closest to the category of industrial landscape, but they have many primary and/or secondary functions that influence the results. It is also possible to observe that certain historical cultural landscape elements are categorized into several groups or types, a phenomenon that represents a potential focus for future research on specific landscapes.

In addition to being used to determine the typology of a landscape, the individual clusters were combined into three higher groupings. Three additional categories were identified in step 15 related to the initial input data on the purpose and use of the individual historical cultural landscape elements. The created groups 
(marked a-c) reflect functional values of the ladscape, based on the extent of human influence, and how people use tangible and intangible landscape heritage. Cluster (a) represents the types of landscape that arose from significant human interventions and tangible heritage prevails (water and industrial landscapes). Cluster (b) contains landscapes created by long-term human activities focused on primarly production, tangible heritage prevails (agricultural and forestry landscapes). Finally, cluster (c) represents landscapes that could be described as serving to protect the landscape heritage, tangible and intangible heritage are equal. These landscape types are associated with cultural values and are often artificially created to represent these values (e.g. a designed landscape). They are also landscapes, that contain and reflect historical events (e.g. a military landscape) and today serve to preserve and represent historical and/or religious values (memorial/religious landscape).

\subsection{Productive landcape}

Water power has been used by humans for hundreds of years, the presence of water and its use conditioned the social or economic development. Water management landscapes were created for the purpose of water retention to be used to generate hydropower or for water transport. The purposes of standing water were water retention (fish farming, flood protection measures, recreational purposes, and drinking water) or energy production (mills and hydroelectric power plants). Water management landscapes closely resemble industrial landscapes (Biswas, Tortajada 2009).

Industrial landscapes were affected by industrial activity. They are characterized by the spatial concentration of industrial and related urban, transport or mining forms of relief and additionally characterized by irreversible transformations in the natural, economic, human and spiritual structure of the landscape. Many industrial landscapes were created during the industrial revolution (i.e. predominantly in the second half of the 19th century). Specific values have been observed in terms of their unique technical, historical or cultural features, economic production or social cohesion between communities. This type of landscape includes a number of subtypes depending on the particular stage of development or the decline of industrial activities. Several authors (Ling, Handley, Rodwell 2007, Kolejka et al. 2012) distinguish many subtypes according to the duration of the activity or the time when the activity was terminated as well as the industrial activity (mining, energy production, light industry, etc.). There are two basic subtypes: (1) industrial (industry-created landscape with attributes that are functional at the time) or (2) post-industrial (industry-abandoned landscape with attributes that are no longer functional). 
It is important to mention here that in the overview of historical cultural landscape types is not the urban landscape (built-up, settled landscape). This type of landscape is often interconnect with industrial landscape, but considering the chosen method of research, attention was paid only to the open landscape in large scale.

\subsection{Harvesting landscape}

As agriculture and forestry represent the first human economic activities, agricultural and forest landscapes occur on all continents and among all human populations and can be referred to the "first cultural landscapes". Both, traditional agricultural and forest landscapes contain mainly environmental values, for example flower meadows. These landscapes are clearly complex and include economic features as well as the technical and cultural historical cultural landscape elements (Kabrda, Jančák 2007).

Forest landscapes are areas densely covered with trees. Such landscapes are highly complex ecosystems consisting of plants, animals and abiotic environment. Among other purposed, a forest landscape has timber (i.e. wood source), recreational, ecological or water management functions. The overall arrangement of the forest landscape is given on the basis of a predetermined compositional intention of the creator (owner). The composition of the forest can represent the position of the owner in society, his property or spiritual values. Historic or cultural value is represented by forests in their own right, such as vegetation-related stands. Such are, for example, forest stands of young origin with long-term development and preserved typical natural and cultural-historical elements of old stumps. Forest landscapes can then also contain other elements, for example related to hunting, historical objects of forest administration, forestry or lumbering (Mather, Needle, Coull 1998; Mansourian et al. 2017).

Agricultural landscapes are mainly used for agricultural purposes, namely, agricultural crops or livestock farming. That is, agricultural crops or livestock farming were key factors in shaping the visual features of rural areas and creating valuable habitats for wildlife. Agriculture is the main land use, and the resulting high visibility results in a widespread perception that "rural" means "farming". The specific appearance of an agricultural landscape depends on many factors. Of particular importance is territorial integrity and the interconnection of individual historical cultural landscape elements and primarily production functions (Marshall 2004). Many examples exist in relation to the degree of development of a given company, the type of production (plant $\times$ animal), the type of holding (crops $\times$ pastures), etc. Each of these subtypes has a completely different visual expression. 


\subsection{Heritage landscapes}

Heritage landscapes can be considered as landscapes that primarily preserve and present cultural or historical values based on the historical cultural landscape elements. Their basic defining factor is that they reflect a historical situation, and thus historical, social or cultural values, and in some way are reminiscent of values and meanings related to the past. A heritage landscape is therefore primarily a collection of specific elements reminiscent of the past.

A heritage landscape may also contain spiritual values that are represented by certain subtypes as designed landscapes. The latter are landscapes that people have modified primarily from an aesthetic point of view. These can be, for example, gardens, parks or cemeteries. Such landscapes are protected for their historical or artistic value and for representing and preserving historical heritage. A designed landscape may include changes in form, water features, builtup structures, trees and plants, all of which may occur naturally (Šantrůčková, Weber 2016). A designed landscape which can be found, for example, in castles or manor houses, was consciously designed by a landscape architect or master gardener.

Another type is the memorial/religious landscape, which is based on interactions between space and memorial/religious manifestations from the local to the global level. We can also note sociocultural transformations associated with this interaction. These landscapes are mostly created from historical cultural landscape elements with religious meaning and are typically the most attentively observed landscapes while being completely specific and individual for every person. In the religious landscape, we understand space (territory or region) as well as society changes according to the space that forms. In the broader sense, the religious landscape is the territory and the society of the selected larger territorial unit, which was influenced by general religious influences, and in the narrower sense of the word, it is the specific sacral objects that complement or even create and determine the landscape character of the area (for example, sacral structures as a dominant feature of the landscape). These landscapes are created by historical cultural landscape elements of religious value (meaning) and are nearly the most subtly perceived landscapes, since the degree of religiosity is very difficult to measure and, at the same time, is completely specific and individual for every person. The degree of religiosity depends on both a particular religion and its active practice. Therefore, the religious landscape could be defined as a set of historical cultural landscape elements with religious themes and religious significance in space. These elements may be scattered buildings or a sacred building or depict the God's life. However, in the case of another geographical area inhabited by the devotees of another religion, the religious landscape would have a completely different form but would be equally religious. The religious landscape has specific 
values in social and cultural dimensions as well as historical, spiritual and integrity dimensions (Knippenberg 2005; Havlíček, Hupková 2013).

Military landscapes, which were created by their preserving of the remains of military conflicts, also serve to memorialize historical events. These landscape forms arose from troop activities. Like other anthropogenic shapes, we could divide them according to their position on the surface and underground and whether they are convex or concave. The meaning and function of historical military landscapes is nearly exclusively symbolic. Most military landscapes have a memorial or educational function. These lands also serve as reminders of war events and their victims. In addition, functional military training areas can include places that have been untouched by man for long periods of time, which therefore represent examples of natural and environmental values (Woodward 2014; Šantrůčková et al. 2020).

\section{Discussion}

Within the framework of the categorization of historical cultural landscapes, seven types of landscapes have been identified. These types can be grouped into three larger units: productive, harvesting, and heritage landscapes. All these landscapes originate in the transformation of natural via cultural to historical cultural landscapes (Sauer 1925). Each of these landscape types represents certain historical and cultural values and is created to fulfil certain specific functions. Productive landscapes in most cases represent large-scale and often irreversible interventions and changes, closely connected to the tangible heritage. These landscapes could have industrial functional values (Ling, Handley, Rodwell 2007), including mining (Conesa, Schulin, Nowack 2008; Wheeler 2008) or water management (Biswas, Tortajada 2009). Typical historical cultural landscape elements include waterworks, mines, quarries and industrial sites. Agricultural and forest landscapes (harvesting landscape) are also represented mainly by tangible heritage. These complex landscapes contain significant amout of the natural historical cultural landscape elements (forest, meadow, pasture, vineyards, etc.) that need nature-friendly management (Kolejka 2014). They serve primerly for food production (forestry, agricultural) often could return to its natural state after a period of human intervention (Forman, Godron 1986). Both, productive and harvesting landscapes are based on the tangible heritage and fulfill the definition of the organically evolved landscape according UNESCO clasification (Rössler 2006).

The third complex of landscapes is heritage landscapes. These landscapes are the most determined by historical and cultural events and importance of intangible heritage. The historical cultural landscape elements were created to commemorate 
Table 2 - The overview of individual identified landscapes and authors who have already defined them in their works

\begin{tabular}{|c|c|c|}
\hline Name of landscape & Source & Specific example \\
\hline Water management landscape & $\begin{array}{l}\text { Biswas, Tortajada (2009); } \\
\text { Erfurt-Cooper (2009) }\end{array}$ & $\begin{array}{l}\text { Rhine-Main-Danube canal } \\
\text { landscape, Germany }\end{array}$ \\
\hline Industrial landscape & $\begin{array}{l}\text { Ling, Handley, Rodwell (2007); } \\
\text { Kolejka (2012) }\end{array}$ & $\begin{array}{l}\text { Dearne Valley in South Yorkshire, } \\
\text { UK }\end{array}$ \\
\hline Forestry landscape & $\begin{array}{l}\text { Mansourian, Stanturf, Derkyi, Engel (2017); } \\
\text { Bürgi et. al. (2020) }\end{array}$ & Sami boreal forests, Sweden \\
\hline Agricultural landscape & Marshall (2004) & Bocage landscape in France \\
\hline Memorial/religious landscape & $\begin{array}{l}\text { Knippenberg (2005); } \\
\text { Havlíček, Hupková (2013) }\end{array}$ & Mikulovsko, Czechia \\
\hline Designed landscape & Šantrůčková, Weber (2016) & Petrohrad and Žehušicko, Czechia \\
\hline Military landscape & Woodward (2014) & The Maginot Line, France \\
\hline
\end{tabular}

Source: authors using the above sources

and preserve history (Esposito, Cavelzani 2006). These landscapes also reflect society's attitude towards nature and culture to the greatest extent. For example, religious landscapes were closely tied to place and to the religion of the region. Thus, they can appear quite different in different parts of the world. Christian society is characterized by historical cultural landscape elements such as churches and crosses (Knippenberg 2005; Havlíček, Hupková 2013). Generally, however, there are memorials or other monuments reminiscent of important persons or events in these countries (Stephenson 2008). A specific example is military landscapes, where, for example, it is possible to find remnants of military objects (e.g., bunkers) that no longer fulfil their original function that occasionally can serve as museums, but in any case recall wars and their victims (Woodward 2014). In this sense, it is also appropriate to use different types of landscape (such as designed landscapes) to illustrate how people have sought to represent their ideologies, interests, or power ideals in the landscape at different times.

Of course, the list of the historical cultural landscape elements couldn't be complete, but the collection of elements represents the universal set for the Central European landscape. The individual types of landscapes mentioned in the description are mentioned by various authors. To summarize all the types mentioned, Table 2 was created, in which the types of landscape arising from the cluster analysis and selected authors who characterize and describe these types of landscapes are listed. The third column of the table contains selected specific examples of localities where these specific landscapes could be found in the European area. However, this is only a selection and the mentioned types of landscapes can of course be found in many other places. 
The proposed categorization of the historical cultural landscapes deepen the categorization proposed by UNESCO for cultural landscapes protected on the international level (Rössler 2006). Application of cluster analysis to the historical cultural landscape elements allow to set up the categorization on the scientific basis. The proposed categorization could be useful for historical cultural landscape heritage protection and identification its strength and weak sides, potential and threats (SWOT analysis; Kučová, Stroblová, Weber 2013). On the other hand, the proposed typology was not applied in the concrete on the model area. The verification of the method and typology on the regional level could bet he next step of the heritage landscapes research.

\section{Conclusion}

There are many different landscape typologies that attempt to define landscape types based on physical geographic factors, land use, social ties, etc. However, little progress has been made towards a general classification of the historical cultural landscape from a socio-historical viewpoint.

This study aims to create a categorization of the types of historical cultural landscapes, e.g. landscapes with significant historical values. The study mainly applies the under-used method of cluster analysis in the field of historical cultural landscape elements. In the research, a selection of 51 basic historical cultural landscape elements was made that contain specific cultural, social, memorial, or other specific values. Based on this selection, seven historical cultural landscape types were defined that display typical historical cultural landscape elements, functions, and values they perform or have performed in the past. In addition, higher degrees of integration of historical cultural landscapes into three units have been defined, which represent specific degrees of human impact, related functions, and observed values. The specific selection of the historical cultural landscape elements included those found in Europe.

The hypotheses were confirmed: (a) The historical cultural landscape types created by the cluster analysis correspond with characteristics of historical landscapes mentioned by other authors. These characteristics and landscaapes were distinguished individually on model areas and are usually focuse on one type of historical cultural landscape; rarely on two or more. On the other hand, the cluster analysis is aimed to categorization of the historical cultural landscapes and do not descibe model areas and examples. (b) The final typology reflects both the ways of human management and functions in the landscape and appreciated values.

However, in view of the universality and the generalizability of the research, it is possible to apply the adopted method to other sets of elements. In future research, it would be advisable to verify the methodology in the field, particularly 
by combining research, whereby the landscape would first be selected based on the choice of specific historical cultural landscape elements and then subjected to cluster analysis and subsequent verification of the historical cultural landscape types, e.g. by terrain research (Paasi 2003, Stephenson 2008).

\section{References}

ANTROP, M.A. (2013): Brief History of Landscape Research. In: Howard, P., Thompson, I., Waterton, E. (eds.): The Routledge Companion to Landscape Studies. Routledge, London, 12-22. ANTROP, M. (1997): The concept of traditional landscapes as a base for landscape evaluation and planning. The example of Flanders Region. Landscape and Urban Planning, 38, 105-117. BENDER, O., BOEHMER, H.J., JENS, D., SCHUMACHER, K.P. (2005): Using GIS to analyse long-term cultural landscape change in Southern Germany. Landscape and Urban Planning, $70,1-2,111-125$.

BERGÈS, L., DUPOUNEY, J.L. (2021). Historical ecology and ancient forests: Progress, conservation issues and scientific prospects, with some examples from the French case. Journal of Vegetation Science, 32, 1-17.

BIČíK, I. (2004): Long term changes in land use of the Czech Republic territory. Životné prostredie, 38, 2, 81-85.

BISWAS, A.K., TORTAJADA, C. (2009): Changing Global Water Management Landscape. In: Water Management in 2020 and Beyond. In: Biswas, A.K., Tortajada, C., Izquierdo, R., (eds): Water Resources Development and Management, Springer, Berlin, 1-34.

BÜRGI, M., CEVASCO, R., DEMETER, L., FESCENKO, A., GABELLIERI, N., MARULL, J., ÖSTLUND, L., ŠANTRŮČKOVÁ, M., WOHLGEMUTH, T. (2020): Where do we come from? Cultural heritage in forests and forest management. In: Krumm, F., Schuck, A., Rigling (eds.): How to balance forestry and biodiversity conservation - A view across Europe. European Forest Institute (EFI) - Swiss Federal Institute for Forest, Snow and Landscape Research (WSL), Birmendorf, 47-61.

CAPELO, S., BARATA, F.T., MASCARENHAS, J.M. (2011): Why are Cultural Landscapes of Various Values? Thinking About Heritage Landscape Evaluation and Monitoring Tool. Journal of Landscape Ecology, 4, 1, 5-17.

CHUMAN, T., ROMPORTL, D. (2010): Multivariate classification analysis of cultural landscapes: An example from the Czech Republic. Landscape and Urban Planning, 98, 3-4, 200-209.

CONESA, H.M., SCHULIN, R., NOWACK, B. (2008): Mining landscape: a cultural tourist opportunity or an environmental problem? The study case of the Cartagena - La Unión Mining District (SE Spain). Ecological Economics, 64, 690-700.

DAUGSTAD, K., GRYTLI, E. (1999): How to study and manage a multihistoric landscape. Norsk Geografisk Tiddskrift, 53, 85-92.

EHRLICH, M., KUČA, K., KUČOVÁ, V., PACÁKOVÁ, B., PAVLÁTOVÁ, M., SALAŠOVÁ, A., ŠANTRŮČKOVÁ, M., VOREL, I., WEBER, M. (2020): Typologie historické kulturní krajiny České republiky. Certifikovaná metodika. Národní památkový ústav, Praha.

ERFURT-COOPER, P. (2009): European Waterways as a Source of Leisure and Recreation. In: Prideaux, B., Cooper, M. (eds.): River Tourism. CAB International, Massachusetts, 95-116. ESPOSITO, M., CAVELZANI, A. (2006): The World Heritage and cultural landscapes. PASOS. Revista de Turismo y Patrimonio Cultural, 4, 3, 409-419. 
FAIRCLOUGH, G. (2016): Essentially cultural: Perspectives on landscape from Europe. Landscape Journal, 35, 2, 149-166.

FORMAN, R.T.T., GODRON, M. (1986): Landscape Ecology. John Wiley \& Sons, New York.

GFELLER, A.E. (2013): Negotiating the meaning of global heritage: 'cultural landscapes' in the UNESCO World Heritage Convention, 1972-92. Journal of Global History, 8, 483-503.

GINÉ, D.S. (2018): A Renewed Approach to the ABC Landscape Method: An Applicatoin to Mentanyes d'Ordal, Barcelona Metropolitan Area. Landscape Online, 56, 1-12.

GULLINOA, P., LARCHER, F. (2013): Integrity in UNESCO World Heritage Sites. A comparative study for rural landscapes. Journal of Cultural Heritage, 14, 5, 389-395.

HARTIGAN, J.A. (1975): Clustering Algorithms. John Wiley \& Sons, New York.

HAVLÍČEK, T., HUPKOVÁ, M. (2013): Sacred Structures in the Landscape: The Case of Rural Czechia. Scottish Geographical Journal, 129, 2, 100-121.

HORÁČEK, M. (2015): Úvod do památkové péče. Univerzita Palackého v Olomouci, Olomouc.

HOWARD, P., THOMPSON, I., WATERTON, E., eds. (2013): The Routledge Companion to Landscape Studies. Routledge, London.

KABRDA, J., JANČÁK, V. (2007): Vliv vybraných politických a institucionálních faktorů na české zemědělství a krajinu. Geografie, 112, 1, 48-60.

KNIPPENBERG, H., eds. (2005): The Changing Religious Landscape of Europe. Het Spinhuis, Amsterdam.

KOLEJKA, J. (2014): Přírodní krajiny České republiky. Katalog typů př́rodních krajin. Masarykova univerzita, Brno.

KOLEJKA, J. et. al. (2012): Postindustriální krajina Česka. Soliton, Brno.

KOLEJKA, J., KREJČÍ, T., NOVÁKOVÁ, E. (2020): The Pre-industrial landscape in Moravia. The case study of inventory and analysis of the ancient land use structures in the Czech Republic. Land Use Policy, 97, 9, 1-10.

KUČERA, Z. (2009): Krajina jako dědictví. In: Heřmanová, E., Chromý, P. et al.: Kulturní regiony a geografie kultury. ASPI, Praha, 156-180.

KUČOVÁ, V., STROBLOVÁ, L., WEBER, M. (2013): Ochrana a péče o historickou kulturní krajinu v České republice prostřednictvím institutu krajinných památkových zón (SWOT analýza). Zprávy památkové péče, 73, 4, 340-346.

KUPKA, J. (2010): Krajiny kulturní a historické. České vysoké učení technické v Praze, Praha.

LATOCHA, A. (2015): Past Human Activities Recorded in the Landscape: A Case Study from the Glenveagh National Park, Ireland. Landscape Research, 40, 3, 338-358.

LIESKOVSKÝ, J., BEZÁK, P., ŠPULEROVÁ, J., LIESKOVSKÝ, T., KOLEDA, P., DOBROVODSKÁ, M., BÜRGI, M., GIMMI, U. (2015): The abandonment of traditional agricultural landscape in Slovakia - Analysis of extent and driving forces. Journal of Rural Studies, 37, 75-84.

LING, CH., HANDLEY, J., RODWELL, J. (2007): Restructuring the post-industrial landscape: a multifunctional approach. Landscape Research, 32, 3, 285-309.

LIPSKÝ, Z., ROMPORTL, D. (2007): Typologie krajiny v Česku a zahraničí: stav problematiky, metody a teoretická východiska. Geografie, 112, 1, 61-83.

LOWENTHAL, D. (1990): Historic landscapes: indispensable hub, interdisciplinary orphan. Landscape Research, 15, 2, 27-29.

LOWENTHAL, D. (2007): Living with and looking at landscape. Landscape Research, 32, 5, 635-656.

MANSOURIAN, S., STANTURF, J.A., DERKYI, M.A.A., ENGEL, V.L. (2017): Forest Landscape Restoration: increasing the positive impacts of forest restoration or simply the area under tree cover? Restoration Ecology, 25, 2, 178-183. 
MATHER, A.S., NEEDLE, C.L., COULL, J.R. (1998): From resource crisis to sustainability: the forest transition in Denmark, The International Journal of Sustainable Development \& World Ecology, 5, 3, 182-193.

MARSHALL, E.J.P. (2004): Agricultural Landscapes: Field Margin Habitats and Their Interaction with Crop Production. Journal of Crop Improvement, 12, 1-2, 365-404.

MERHAUTOVÁ, Z. (2009): Typologie krajiny v oblasti Českého ráje. Katedra fyzické geografie a geoekologie, Př́rodovědecká fakulta, Univerzita Karlova. Thesis.

MITCHELL, D. (2008): New Axioms for Reading the Landscape: Paying Attention to Political Economy and Social Justice. In: Wescoat, J.L., Johnston, D.M. (eds.): Political Economies of Landscape Chang. Springer, Dordrecht, 29-50

MORGAN, J.L., GERGEL, S.E. (2010): Quantifying historic landscape heterogeneity from aerial photographs using object-based analysis. Landscape Ecology, 25, 7, 985-998.

PAASI, A. (2003): Region and place: regional identity in question. Progress in Human geography, $27,4,475-485$.

PĂTRU-STUPARIU, I., PASCU, M., BÜRGI, M. (2019): Exploring Tangible and Intangible Heritage and its Resilience as a Basis to Understand the Cultural Landscapes of Saxon Communities in Southern Transylvania (Romania). Sustainability, 11, 11, 3102.

PRATS, M., SALIN, E. (2016): Cultural landscape: a promising category. In: Kiss, F., Bassa, L. (eds.): Proceedings of TCL 2016 conference. Infota, Budapest, 451-465.

RIEGL, A. (2003): Moderní památková péče. Národní památkový ústav, Praha.

ROMPORTL, D., CHUMAN, T. (2012): Present Approaches to Landscape Typology in the Czech Republic. Journal of Landscape Ecology, 5, 3, 24-35.

ROMPORTL, D., CHUMAN, T., LIPSKÝ, Z. (2013): Landscape typology of Czechia. Geografie, $118,1,16-39$.

RÖSSLER, M. (2006): World Heritage Cultural Landscapes: A UNESCO Flagship Programme 1992-2006. Landscape Research, 31, 4, 333-353.

RUDEL, T.K., SCHNEIDER, L., URIARTE, M. (2010): Forest transitions: An introduction. Land Use Policy, 27, 2, 95-97.

SAUER, C.O. (1925): The morphology of landscape. University of California Press, Berkeley.

SCAZZOSI, L. (2004): Reading and assessing the landscape as cultural and historical heritage. Landscape Research, 29, 4, 335-355.

SCHULTE, L.A, MLADENOFF, D.J., NORDHEIM, E.V. (2002): Quantitative classification of a historic northern Wisconsin (USA.) Landscape: mapping forests at regional scales. Canadian Journal of Forest Research, 32, 1616-1638.

SIRISRISAK, T., AKAGAWA, N. (2007): Cultural landscape in the world heritage list: understanding on the gap and categorisation. City \& Time, 2, 3, 11-20.

SMITH, L. (2006): The Uses of Heritage. London, Routledge.

SKOKANOVÁ, H., EREMIÁŠOVÁ, R. (2012): Changes in the secondary landscape structure and the connection to ecological stability: the cases of two model areas in the Czech Republic. Ekológia (Bratislava), 31, 1, 33-45.

STEPHENSON, J. (2008): The Cultural Values Model: An integrated approach to values in landscapes. Landscape and Urban Planning, 84, 127-139.

ŠANTRU゚ČKOVÁ M., SALAŠOVÁ, A., SOKOLOVÁ, K., SEDLÁČEK, J. (2020): Mapping military landscape as a cultural heritage: case study of the Austerlitz/Slavkov battlefield site. AUC Geographica, 55, 1, 66-76. 
ŠANTRŮČKOVÁ M., WEBER M. (2016): Identification of Values of the Designed Landscapes: Two Case Studies from the Czech Republic. In: Agnoletti, M, Emanueli, F. (eds.): Biocultural Diversity in Europe. Environmental History. Springer, Cham, 487-509.

TAPPEINER, U., LEITINGER, G., ZARINA, A., BÜRGI, M. (2020): How to consider history in landscape ecology: patterns, processes, and pathways. Landscape Ecology, https://doi. org/10.1007/s10980-020-01163-w.

TAYLOR, K., LENNON, J. (2011): Cultural landscapes: a bridge between culture and nature? International Journal of Heritage Studies, 17, 6, 537-554.

TAYLOR, R.D., SCHEJTER, A.M. (2013): Beyond Broadband Access: Developing Data-Based Information Policy Strategies. Fordham University Press, New York.

TRYON, R.C. (1939): Cluster Analysis: Correlation Profile and Orthometric (Factor) Analysis for the Isolation of Unities in Mind and Personality. Edwards Brothers, Ann Arbor.

TURNER, S. (2018): Historic landscape characterisation: an archaeological approach to landscape heritage. In: Fairclough, G., Sarlov-Herlin, I., Swanwick C. (eds.): Routledge Handbook of Landscape Character Assessment. Routledge, London, 37-50.

VAN EETVELDE, V., ANTROP, M. (2009): A stepwise multi-scaled landscape typology and characterisation for trans-regional integration, applied on the federal state of Belgium. Landscape and Urban Planning, 91, 3, 160-170.

VOREL, I. (2005): Historické krajinné kompozice - dominantní znaky kulturní a historické charakteristiky krajinného rázu. In: Maděra, P., Friedl, M., Dreslerová, J. (eds.): Krajinný ráz - jeho vnímaní a hodnocení v evropském kontextu. Paido, Brno, 201-204.

WHEELER, R. (2008): Mining memories in a rural community: Landscape, temporality and place identity. Journal of Rural Studies, 36, 22-32.

WOODWARD, R. (2014): Military landscapes. Agendas and approaches for future research. Progress in Human Geography, 38, 1, 40-61.

\section{ACKNOWLEDGEMENT}

The research in Czechia was funded by institutional support from the Silva Tarouca Research Institute for Landscape and Ornamental Gardening (VUKOZ-IP-00027073).

\section{ORCID}

JAKUB JELEN

https://orcid.org/0000-0002-7455-1548

MARKÉTA ŠANTRŮČKOVÁ

https://orcid.org/0000-0003-1519-8235

MAREK KOMÁREK

https://orcid.org/0000-0003-3365-2921 